Revista

A Cor

das Letras

\title{
A semiótica greimasiana sob aspectos fenomenológicos: uma relação de sentido
}

\section{The greimasian semiotics under phenomenological aspects: a relation of sense}

\author{
Suani de Almeida Vasconcelos* \\ Universidade Estadual de Feira de Santana \\ Feira de Santana, Bahia, Brasil
}

\begin{abstract}
Resumo: O presente trabalho apresenta considerações que envolvem a relação entre a fenomenologia com os estudos em linguagem, mais especificamente no campo da significação, focalizando o trabalho do lingüista Algirdas-Julien Greimas - Semiótica Textual. Para tal, fez-se um breve retrospecto teórico, a partir da filosofia platônica (séc. V a.C), chegando até os filósofos contemporâneos no campo da Filosofia da Linguagem, os quais serviram de base para o arranjo lógico-semiótico e fenomenológico moderno, desembocando na teoria greimasiana sobre a significação e o processo interpretativo.
\end{abstract}

Palavras-chaves: Linguagem. Filosofia da Linguagem. Semiótica Textual

\begin{abstract}
The present work presents considerations that involve the relationship between phenomenology and language studies, more specifically in the field of signification, focusing on the work of the linguist AlgirdasJulien Greimas - Textual Semiotics. For this, a brief theoretical review was made, starting from Platonic philosophy (5th century BC), reaching up to contemporary philosophers in the field of Philosophy of Language, which served as the basis for the logical-semiotic and modern phenomenological arrangement, Ending in the greimasiana theory on the signification and the interpretative process.
\end{abstract}

Keywords: Language. Philosophy of Language. Textual Semiotics

Compreender as teorias que dão conta do estudo sígnico depende fundamentalmente de se levar em conta aspectos perceptivos que integram, numa mesma dimensão de sentido, o interpretante (sujeito cognoscente) e o "objeto" a ser interpretado (objeto cognoscível). E com a semiótica textual não poderia ser diferente, haja vista que esse campo de interesse da significação não prescinde do(s) sujeito(s) da linguagem nem da matéria mesma de observação (a língua) num processo mediado pelos sentidos que operam a ação complexa do interpretar.

A língua e sua dimensão discursiva e seus imbricamentos, no campo comunicacional, que materializam a ação humana no mundo, levaram linguistas, filósofos e até mesmo cientistas sociais, no percurso da tradição científica ocidental, a perscrutarem sobre a linguagem como um arcabouço cultural estruturante do real e seu estatuto axiológico e relacional entre os homens.

As preocupações em torno das noções de percepção e sentido não são recentes, ao contrário, já ocupavam as observações dos gregos da antiguidade clássica, especialmente em Platão [séc.V a.C] e Aristóteles [séc.IV a.C.], apresentadas sob a forma de estudos de categorias gramaticais, nos quais se buscava entender a relação entre o nome (denominação) e a coisa denominada, assim como se essa denominação estaria ligada à percepção de quem observa ou se a atribuição aparece no plano superficial das palavras daquilo que já está na essência do que se observa.

* Doutra em Letras e Linguística, professora da Universidade Estadual de Feira de Santana. Email: suanivasconcelos@bol.com.br. 
Em $A$ República, no livro VI, Platão ([V.a.C], 1996), antecedendo as discussões posteriores do "mito da caverna", nessa mesma obra, já problematiza, em sua dialética, as noções distintivas entre o mundo sensível (visível) e mundo inteligível, explicitando, por meio da metáfora do sol, num diálogo entre Sócrates e Glauco, como o mundo sensível é percebido pelo homem. No diálogo, Sócrates afirma que a percepção do visível só é possível porque os raios do sol atingem e iluminam as coisas; então, o homem, nessas circunstâncias, tem apenas uma percepção proporcional àquilo que é iluminado e, em contrapartida, não percebe também o que não é dado ser visto pela luz solar. Nessa perspectiva, essa seria a condição humana, a percepção do mundo visível, "segundo sua claridade ou obscuridade relativa" (Platão [V.a.C], 1996, p.313). Já no campo do mundo inteligível, este é pensado ou a partir das imagens do mundo percebido, por meio de hipóteses que levam às conclusões, dispensando-se as investigações do princípio absoluto; ou, sem levar em conta as imagens, parte-se a caminho da investigação do princípio, valendo-se apenas das próprias ideias. Apreende-se, então, a classe do inteligível quando,

A alma é obrigada a servir-se de hipóteses ao procurar investigá-la, sem ir ao princípio, pois não pode elevar-se acima das hipóteses, mas utilizando como imagens os próprios originais do quais eram feitas as imagens pelos objectos da secção inferior, pois esses também, em comparação com as sombras, eram considerados e apreciados como mais claros. (PLATÃO [V.a.C], 1996, p.315)

$\mathrm{Na}$ esteira do pensamento platônico, observa-se que o mundo circundante e o sentido de realidade que este apresenta ao observador são, na verdade, fruto de uma percepção "falseada", em sua origem, haja vista que este mundo, aparentemente tão real e sólido, é uma "cópia" do mundo ideal. Apresenta-se, assim, o simulacro da "idealidade", entendida, neste contexto, como o mundo perfeito e original (mundo das idéias), do qual percepção humana é incapaz de antever, restando-lhe sua "sombra" ou cópia como uma realidade mais próxima e possível, conforme Sócrates dialoga: “[...] Chamo imagens, em primeiro lugar, às sombras; seguidamente, aos reflexos nas águas, e àqueles que se formam em todos os corpos compactos, lisos e brilhantes, e a tudo o mais que for do mesmo gênero, se estás a entender-me". (PLATÃO [V a.C], 1996, p.313-314)

Acrescem-se a esse entendimento as reflexões apresentadas em "o mito da caverna", uma narrativa cujos personagens encontram-se agrilhoados, em um local subterrâneo (caverna), iluminados apenas por uma pequena fogueira e só conseguem ver as sombras projetas nas paredes pela única fonte de luz disponível. Ora, tudo aquilo, então, que esses personagens denominassem ou mesmo nomeassem seria fruto da percepção dessas sombras, e mais, tais sombras seriam tomadas como a coisa real e não sua projeção por contraste de luz. A realidade percebida estaria, assim, na relação direta com esse ambiente e daquilo que circulasse nele, como também aquilo que se podia ouvir, ou seja, o eco das vozes que viam de fora seria percebido como som presente no ambiente.

Esse contexto narrativo exemplifica a fundação da ideia capital do platonismo que é a dualidade entre forma e ideia e, consequentemente, a instauração dos simulacros, isto é, das representações originárias da percepção das coisas mediadas pela linguagem, denominando-as ou nomeando-as e, dessa forma, construindo um sentido de realidade e possibilitando o estar no mundo nas suas mais diversas formas.

O simulacro, pois, interioriza as cópias e ícones, implicando num efeito de similitude tal que o sujeito observador não distingue as cópias das coisas, haja vista que ele mesmo (o sujeito observador) é elemento constituinte dessa experiência de simulacro. 
O simulacro implica grandes dimensões, profundidades e distâncias que o observador não pode dominar. É porque não as domina que ele experimenta uma impressão de semelhança. O simulacro inclui em si o ponto de vista diferencial; o observador faz parte do próprio simulacro, que se transforma e se deforma com seu ponto de vista. (DELEUZE, 2004, p. 6)

A semelhança, portanto, com esse mundo ideal será representada pelas boas imagens ou ícones, fazendo da dissimulação o mundo das representações, pois, conforme Deleuze (2004, p.4), "se as cópias ou ícones são boas imagens e bem fundadas, é porque são sempre dotadas de semelhança".

Dessa forma, a percepção é também algo que é "falseado", pois que advém também de um mundo "falseado" e não original. Entretanto, vale ressaltar que perceber as coisas não é apenas compará-las ou mesmo tomá-las em sua materialidade, mas, sobretudo, identificá-las com a ideia que se tem das coisas, pois são aquelas que percebem e interpretam o mundo circundante e não as coisas em si (DELEUZE, 2000).

Entender a noção de simulacro, a partir dessa dimensão platônica, torna-se questão central das discussões semióticas, uma vez que as relações conceituais entre imagem ícone e simulacros requerem um olhar mais atento nas pequenas variâncias de aplicação e denominação. A imagem e a cópia estabelecem uma espécie de relação identitária e com certa similaridade com a coisa representada, enquanto que a noção de simulacro interioriza a dissimilitude com a coisa representada, o que estaria mesmo na essência conceptual da dialética platônica (mundo das ideias e mundo das formas). O simulacro, então, é compreendido não como algo semelhante ao representado, mas como a internalização da corrupção e das imperfeições desse mundo original.

Se dizemos do simulacro que é uma cópia de cópia, um ícone infinitamente degradado, uma semelhança infinitamente afrouxada, passamos à margem do essencial: a diferença de natureza entre o simulacro e cópia, o aspecto pelo qual formam as duas metades de uma divisão. A cópia é uma imagem dotada de semelhança, o simulacro, uma imagem sem semelhança. (DELEUZE, 2000, p.05)

Como a percepção se dá mediante os sentidos que se traduzem por pensamentos, os quais se materializam como linguagem, esta, então, desempenha um papel fulcral na dinâmica perceptiva e mediativa do homem no mundo. Palco das relações e das significações humanas, presentifica e (re)presentifica os modos de estar no mundo, constituindo toda uma realidade imediata, que proporciona uma aparente relação direta com as coisas, pessoas etc., e, consequentemente, até mesmo com as sensações experienciadas, definindo-as, caracterizando-as e nomeando-as, como, por exemplo, saudade, ciúme, raiva, paixão etc. A linguagem, assim, realiza um simulacro, uma realidade construída por meio de um artifício simbólico, forjado nas relações sócio-culturais, no qual é possível significar ou dar significação, nessa mesma realidade, materializando, inclusive, o que se sente.

Ainda no viés das similitudes epistêmicas entre percepção e significação, Greimas (1976 [1966], p.15) afirma, categoricamente, "com conhecimento de causa", que considera a "percepção como o lugar não lingüístico onde se situa a apreensão da significação". Ora, tal assertiva, além de corroborar o fundamento platônico, consegue estabelecer a interação fenomenológica e semiótica, apontando na direção de que é o homem o elemento primordial na operacionalização do mundo da significação, uma vez que é nele - o homem - que a percepção significativa, articulada e traduzida pela linguagem, acontece. Some-se a isso, ainda de acordo com Greimas e Fontanille (1993, p.15), a representação do estatuto "fenomenal e paradoxalmente 'real' ao mesmo tempo" 
do objeto semiótico, haja vista que a significação é simultaneamente um constructo do sujeito significante (aquele que atribui significado), como também a sua própria experiência de realidade.

O simulacro engendrado pela linguagem é, sob esse olhar, um modo de "existência semiótica", uma forma de "ser" e de "existir", cuja elaboração do sentido e, mais propriamente, da significação, emerge necessariamente dos sujeitos significantes, em suas manifestações discursivas. A semiose, assim, é condição necessária de existência do sujeito da linguagem que "pela mediação do corpo [...] percebe que o mundo transforma-se em sentido"; e mais, significando tudo que o rodeia, é "que as figuras exteroceptivas interiorizam-se e que a figuratividade pode então ser concebida como modo de pensamento do sujeito" (GREIMAS; FONTANILLE, 1993, p.13).

Os mundos objetal e abstrato, nesse circuito de ação, não mais se apresentam, mas sim se representam, ou seja, adquirem existência significativa, na medida em que são apreendidos pelo homem, mais propriamente, quando se formula o conhecimento sobre esses mundos por meio da imaginação humana, mobilizando, dessa forma, recursos de natureza simbólica, como assinala Duran (1988, p. 59): “As coisas só existem através da 'figura' que lhes dá o pensamento objetificante, elas são eminentemente 'símbolos', já que só se mantêm na coerência da percepção, da concepção, do julgamento ou do raciocínio pelo sentido que as impregna”.

O sentido atribuído ao mundo circundante, elaborado por meio da racionalidade, no processo de semiose, em um trânsito simbólico, pode ser associado ao reconhecimento dos vários aspectos constituintes da vida pela consciência humana, produzindo um efeito de sensibilização do campo emocional do homem (foria), o que dispara o gatilho fórico, no processo de identificação dos valores objetais ou abstratos, materializados pela linguagem, nesse campo de abordagem, entendido como semas.

Os semas, assim, para adquirirem sentido, se distinguiriam dentre outros, na composição inicial do percurso de significação, opondo-se e revelando-se ao sujeito interpretante por um processo que, de acordo com a perspectiva semiótica de Petitot (1977 apud LOPES, 2006, p.07), denominado de "pregância assemântica". Uma vez identificados, ou seja, sobrelevados, no conjunto sêmico, e topologicamente articulados na estrutura opositiva, por meio do processo perceptivo, esses semas operariam a significação, sintaticamente, em o nível subsequente, o que, de fato, configuraria o sentido manifestado, que, de acordo com a perspectiva de Lopes (2006, p.08), "sua significação, inacessível por via direta, tem de ser encenada de modo mediato pelos percursos sintáxicos da circulação dos objetos entre sujeitos (sintaxe narrativa)".

Tal percurso operatório, que se inicia em o nível fundamental e desemboca no discursivo, acontece mediante o fenômeno perceptivo dos semas, na primeira instância do percurso, que, por conversões subsequentes, adquirem estatuto axiológico e figurativo, compondo, finalmente, o plano do percurso da significação mais superficial, a manifestação discursiva.

Ampliando-se a importância conceitual dos simulacros e apresentando-os, no campo da práxis semiótica, vê-se que, na perspectiva da "semiótica das paixões", Greimas e Fontanille (1993) salientam e evidenciam a centralidade do simulacro, na operacionalização dos sujeitos modais, no qual se configura as relações fóricas estabelecidas entre esses sujeitos.

No plano narrativo, por exemplo, o processo de modalização dos actantes é construído e manifestado por meio do simulacro existencial desses sujeitos e das ações desenvolvidas por ele. Essas ações e relações, pelo querer, que os actantes realizam, simulam o fazer e o ser, os quais geram os "imaginários passionais" que são os "espaços semióticos imaginários", cujo sentido é percebido no plano discursivo. 
O exame dos simulacros existenciais modais conduz-nos, pois, a conceder um papel fundamental às cargas modais na constituição dos imaginários passionais: imiscuindo-se entre o enunciado narrativo e sua efetuação no discurso, a carga modal abre um espaço semiótico imaginário em que o discurso passional pode desfraldar-se. (GREIMAS; FONTANILLE, 1993, p.55)

É ainda no simulacro, na vertente da semiótica passional, que é exercida uma função interessante, conforme Greimas e Fontanille (1993), no tocante a ação debreática dos sujeitos actanciais, uma vez que é, nesse espaço semiótico, que as relações entre sujeitos se realizam e podem se manifestar. Dessa forma é que se convertem, no plano discursivo, os sentimentos (ciúme, medo, alegria etc.), virtualizados no plano imediatamente anterior ao plano superficial, o qual manifesta os efeitos entre os simulacros, tanto entre os sujeitos actanciais, quanto desses com o sujeito interpretante. Assim,

Toda comunicação é comunicação (e interação) entre simulacros modais e passionais: cada um dirige seu simulacro ao simulacro de outrem, simulacros que todos os interactantes, bem como as culturas às quais eles pertencem, ajudaram a construir. (GREIMAS; FONTANILLE, 1993, p. 59)

As relações tensivas, que se manifestam discursivamente, também ocorrem e ganham sentido nesse "espaço semiótico" elaborado pelo simulacro. As sensações produzidas pelos sujeitos semióticos, no campo fórico, em junção com o(s) objeto(s) de valor, afetam a percepção dos sujeitos partícipes da semiose, cujos esquemas proprioceptivos encontram, dessa forma, sua realização por meio de "formas de vida" (FONTANILLE; ZILBERBERG, 2001), as quais dão sentido ao fazer semiótico.

Ademais, o "espaço semiótico" possibilita a (re)dimensão do fazer das relações humanas, oriundas do campo macrossemiótico, o qual se materializa em narrativas axiologicamente investidas de sentido que traduzem uma certa coerência com as maneiras de vida presentes no mundo circundante, uma vez que "toda manifestação de uma forma de vida é então considerada como um condensado da forma de vida inteira" (FONTANILLE; ZILBERBERG, 2001, p.203).

Percebe-se, então, como a realidade fenomênica, nessa escolha de análise, além de complexa, desempenha papel importante e bastante peculiar na elaboração do sentido, como também este é elaborado, tomando-se o homem em seu conjunto social, cultural e ideológico e, sobretudo, emocional, entendido em sua esfera tímica (fórica) de ação perceptiva.

Como visto, a orientação semiótica, na abordagem fenomênica, desvela e revela os momentos quase que originais da significação, radicando-se na esfera dos conceitos e abordagens da linguística moderna e em seus desdobramentos e entrelaçamentos no campo das filosofias clássica e moderna. A extensão da ação perceptiva abrange tanto a significação quanto o ato interpretativo, já que ambos fazem parte de uma mesma operação de linguagem, pois nada significa se não for, de alguma forma, interpretado.

A língua, e mais propriamente a palavra, nessa orientação, actoriza um papel fundamental na elaboração e materialização do pensamento humano, organizando e ordenando aquilo que é percebido e sentido e, consequentemente, possibilitando o processo da significação. Mas a palavra apenas fornece uma aproximação, no mundo da cultura, daquilo que é percebido pelo homem, dando a impressão, de fato, de ser a coisa percebida.

As línguas naturais conseguem muito bem criar essa "ilusão" perceptiva, uma vez que as mesmas constituem-se como conjunto significante (GREIMAS, 1976 [1966]). Ainda de acordo com Greimas (1976 [1966], p.20), um língua natural "pode ser transposta e realizada numa ordem 
sensorial diferente", ou seja, consegue traduzir, por meio de signos, outras formas de percepção, a exemplo dos sonhos (imagens oníricas).

$\mathrm{Na}$ atenção sobre a complexidade, que são as línguas naturais e seu constituinte sígnico, destaca-se, historicamente, F. de Saussure (2003 [1916]), que, em sua obra inaugural, Cours de linguistique generale, capítulo 3, apresenta o lugar que a língua ocupa nos fatos humanos, afirmando ser esta "um sistema de signos que exprimem ideias" e que os signos, portanto, são os mediadores da relação homem-mundo, possibilitando a manifestação e objetivação de ações de natureza subjetiva.

Como sistema metassemiótico, isto é, aquele que permite a interpretação a partir dos seus próprios constituintes (o signo), a língua desempenha um papel de excelência no processo mediador do homem-mundo e homem-homem, bem como da apreensão dos objetos que o cercam. Portador da linguagem e usuário desta, nas mais diversas situações da vida e no mais profundo e solitário ato de pensar até nas dimensões da comunicação coletiva, o ato hermenêutico do homem o faz diferente de outros seres da natureza transformando-o e transformando-se continuamente.

A perspectiva semiológica da língua não é pacífica, uma vez que se tornou tema de várias especulações em torno do valor social da língua e suas manifestações, principalmente no que tange à relação sentido e referência, ou seja, o sentido (significação) de um enunciado está vinculado necessariamente a uma "coisa" no mundo externo para o qual se refere? Ou o contrário, como é possível a significação, o entendimento de um enunciado quando este a nada se refere no mundo exterior?

Interessa apontar alguns filósofos que se ocuparam com campo da linguagem e suas relações com o homem. No contexto histórico dessa abordagem temática, não se pode deixar de mencionar, mais uma vez, as preocupações de Platão (século V a.C) no Crátilo, tratado primeiro sobre a relação linguagem e conhecimento, até as abordagens da filosofia lógico-analítica com as Investigações filosóficas (1953), de Ludwig Wittgenstein (considerado pelo grupo de Oxford como "pai da filosofia lingüística”).

Ambas as obras, consideradas como pontos extremos, e não menos fundantes de uma mesma reflexão na tradição do pensamento ocidental, problematizam aspectos fulcrais quanto à compreensão de como nomes (palavras) e coisas se ordenam no mundo por meio da linguagem e como o sentido se constitui a partir dessa relação.

Platão (V a.C), na obra supracitada, apresenta, utilizando-se do recurso metodológico do debate, uma apreciação crítica entre Sócrates, Hermógenes e Crátilo sobre duas questões pontuais: uma de natureza lógica (se os nomes são frutos das convenções), tese defendida por Hermógenes, e outra de natureza ontológica (se os nomes representam essencialmente as coisas que nomeiam), tese defendida por Crátilo; a personagem socrática (Sócrates é investido daquilo mesmo que foi enquanto mestre) conduz o diálogo, sem perder de vista o caráter dialético das questões numa atitude provocativa e irreverente.

Nomear e significar já despontam, nessa querela filosófica, como uma das primeiras inquietações, de forma sistematizada e de natureza ontológica, sobre a linguagem e seu uso, haja vista que nomear e significar é, sobretudo, pô-la em funcionamento, criando condições únicas que fazem distinguir os homens entre as coisas, e mais, segundo Pinheiro (2003, p.32), "admitir que essa remissão ao onto-ontológico, uma vez referida ao conhecimento, constituirá o núcleo genuinamente platônico de uma análise da linguagem e da comunicação".

As análises platônicas deflagram, assim, o que irá ser conhecido, ao longo de uma extensa trajetória, no campo da especulação filosófica sobre a linguagem, como uma preliminar reviravolta Linguística na Filosofia, consolidando-se, mais tarde (séculos XIX e XX), nos trabalhos dos 
pensadores lógico-matemáticos de Cambridge (Inglaterra), tendo como precursores os alemães Johann Gottlob Frege (Conceitografia, 1879), Bertrand Russell (Princípios de matemática, 1903) e Ludwig Wittgenstein (Tractatus logico-philosophicus, 1921). Pode-se acrescer a tal reviravolta, que não só especificamente, no campo filosófico, que se deram as mudanças de perspectivas investigativas, mas também no viés da tradição dos estudos das línguas naturais, quando o objeto de estudo (as línguas naturais) é alçado de um patamar histórico-evolutivo para uma abordagem imanentesincrônica, sob a égide da ciência moderna de cunho estruturalista, no caso, a linguística estrutural saussuriana.

Importa destacar, antes das breves considerações sobre as contribuições daqueles que pensaram a linguagem como uma alternativa possível para a compreensão do real, que o século XX despontou ainda com essas questões incômodas sobre a relação homem-mundo, mas, ao contrário de antes, as perquirições sobre a linguagem ganham ainda mais importância, na medida em que essa é tomada como uma fonte mais básica, como também sistemática, de se chegar aos fundamentos da significação.

Antecipando as perspectivas modernas sobre a linguagem, percepção e significação, como também a noção de signo, no que tange à sua função mediadora do ato do conhecimento e do comunicativo, fazem-se algumas breves considerações sobre as especulações de Aurelius Agostinho (IV d.C), conhecido, na tradição ocidental, como Santo Agostinho, em sua obra pedagógica De Magistro, na qual apresenta preocupações sobre o acesso à verdade e o ensino pela linguagem, como também a utilidade dessa. Nesse viés pedagógico, Agostinho problematiza, já que esta é a questão dorsal do seu texto, como é possível educar e, por desdobramento, qual a função desempenhada pela linguagem, nesse processo, uma vez que essa, além de ser permeada por equívocos da mente e da vontade humana, nem sempre exprime instrução. Ora, para o bispo de Hipona, a linguagem prescinde do ato fundamental de ensinar, ou seja, exprime-se por meio da linguagem sem que contenha, necessariamente, algo de útil, mas, no entanto, nenhum mestre pode prescindir dela (a linguagem), em seu labor docente (docere).

$\mathrm{Na}$ relação dialógica entre Agostinho e Adeodato (seu filho), a noção de signo aparece numa proximidade clara explícita com a palavra, como também da ação remissiva que a palavra (signo) desempenha com a coisa à qual se refere, tanto no âmbito da materialidade circundante, quanto no campo das emoções, haja vista que até os pensamentos mais íntimos são "pensados" como signos, conforme se nota no capítulo1, $\ 2$,

Agostinho: _ [...] Por essa razão, suponho que, embora alguém o discuta, tu apreendas, ao mesmo tempo, também, que _ inclusive quando não emitimos nenhum som _ falamos no interior de nosso coração, enquanto pesamos as mesmas palavras; e de que, portanto, com a locução não fazemos outra coisa senão recordar, quando a memória, onde as palavras estão impressas, reevocando-as faz vir à mente as coisas mesmas (res ipsas), das quais as palavras são signos. (AGOSTINHO [IV d.C], 2009, p.75, grifo nosso).

A dimensão perceptiva da palavra e como essa encontra ressonância naquele que a ouve ou que a pronuncia encontra também, nesses diálogos, um espaço para sua discussão e entendimento. Mais adiante, Agostinho ([IV d.C.], 2009, p.77) argumenta, por meio de uma pergunta retórica, que mesmo a palavra, numa tomada imediata, a nada se refere ou significa; quando pronunciada, realiza uma ação de "afecção da alma", ou seja, atinge de alguma forma a percepção daquele que a exprime, como também a do seu interlocutor, como se pode observar no capítulo 2, \3,:Agostinho: “ _ [...] Diremos que com esta palavra [nada] não se significa uma coisa que não existe, mas, sim, uma afecção da alma, quando esta não vê uma coisa, mas descobre ou crê ter descoberto que essa coisa não existe?”. 
Adiantando-se na história e a caminho da tradição filosófica moderna, encontra-se uma outra expressiva contribuição teórica do campo da abordagem sobre o signo que são as reflexões perquiridoras do filósofo inglês John Locke (séc.XVII), as quais assomam-se à questão central que envolve linguagem, pensamento e a apreensão das ideias e a aquisição do conhecimento. Partindo de seu principal fundamento de que as ideias não são inatas, mas adquiridas, Locke (séc. XVII), em seu Ensaio sobre o entendimento bumano, capítulo 1, $\int 3$, apresenta a sensação, fruto da percepção humana, como fonte primária de conhecimento, priorizando, assim, os sentidos na fase inicial de aquisição e formação das ideias, a saber: Primeiro, nossos sentidos, familiarizados com os objetos sensíveis particulares, levam para a mente várias e distintas percepções das coisas, segundo os vários meios pelos quais aqueles objetos os impressionaram (LOCKE 1991 [1690], p.27).

É notório que, nessa perspectiva crítica do inatismo, a percepção das coisas e o efeito que produzem são a matriz do pensamento gerado pelo homem, tomando-se, como se vê, o primado do contato (objetivo ou subjetivo) com o elemento que sensibiliza os sentidos humanos como se fosse o detonador do conhecimento. A forma como o homem elabora suas ideias e como as realiza no mundo baseia-se, fundamentalmente, na percepção extraída desse contato que, mediado pela linguagem, opera, por desdobramentos, em uma cadeia de ideias reflexivas, como a ação de duvidar, de crer, de raciocinar, de conhecer, de querer etc., (Locke [1690], 1991) e, assim, suprindo carência de novos entendimentos, de novos conhecimentos.

Esforços e tentativas de se compreender a relação entre o signo e o pensamento encontram, nos gramáticos de Port-Royal (século XVII), mais um campo de debate e análise. Em meio às disputas filosóficas e teológicas, a Grammaire Générale et Raisonnée (Gramática Geral e Razoada) surge como uma obra importante na apresentação das ideias sobre como os signos podem dar conta dos pensamentos. Assim, em seu primeiro capítulo, seus autores Arnauld e Lancelot (2001 [1694]) partem da definição de palavra, a qual é tomada pelo elemento humano e é transformada em signos, ajustando-se a(s) sua(s) significação(ões) àquilo que correspondem os pensamentos.

Assim se pode definir as palavras: sons distintos e articulados, que os homens transformaram em signos para significar seus pensamentos. É por isso que não se pode compreender bem os diversos tipos de significação que as palavras contêm, se antes não se tiver compreendido o que se passa em nossos pensamentos, pois as palavras foram inventadas exatamente para dá-los a conhecer. (ARNAULD; LANCELOT, 2001 [1694], p.29)

As considerações sobre a importância da linguagem, e mais propriamente dos signos, foram decisivas para, na contemporaneidade, outros pensadores desenvolverem e alargarem seus estudos, envolvendo, inclusive, outras áreas de conhecimento, aparentemente díspares, como a matemática e a lógica.

Nessa esteira, de meados do século XIX até o século XX, em sua primeira metade, destacam-se, dentre outros estudos, os trabalhos de L. Wittgenstein. Salientam-se, nesse transcurso, as Investigações Filosóficas, em cujo texto o referido autor desconstrói e problematiza (reflexão analítica), passo a passo, certas compreensões que haviam sido empreendidas pelos filósofos clássicos sobre a linguagem, a exemplo do domínio vulgar de que "cada palavra da linguagem designa algo" (WITTGENSTEIN, [1953], 1999, p.31). Wittgenstein verticaliza a análise dessa assertiva, assim como outras obras anteriores ao Tractatus logico-philosophicus (1921), apontando, então, que absolutamente nada terá sido dito, enquanto não se esquadrinhar e se demarcar o que se quer diferenciar entre as palavras designativas, melhor explicitando, entre aquelas dotadas de significação e aqueloutras que apenas representam um mero som, como um toc-toc de uma personagem batendo à porta, por exemplo, em uma determinada narrativa. 
Apresenta também, no seu empreendimento analítico sobre a linguagem, em sua fase posterior ao Tractatus, conhecido como o "segundo Wittgenstein", a noção de "jogos de linguagem", conceito central e fundante nas perspectivas de análise sobre a linguagem, em cuja abordagem se introduz a práxis, os usos que os utentes fazem da linguagem, como uma nova dimensão de se compreendê-la, asseverando que "representar uma linguagem significa representar-se uma forma de vida" (WITTGENSTEIN, 1999 [1936], p.32).

Outra questão desponta para a compreensão da linguagem e seu uso que diz respeito ao sentido de verdade que as sentenças veiculam. Não se trata mais de entender como a significação se estabelece, mas também quais sentidos de verdade estão ali presentes e mesmo como tais sentidos podem ser percebidos numa sentença que contém uma afirmação falsa. Tentando minimizar essa dificuldade de compreensão entre sentido, referência e veridicção, Gottlob Frege (XIX), anteriormente a Wittgenstein (XX), afirma que só é passível de descrição a relação sentido e referência, sendo heuristicamente produtiva tal abordagem, contrariamente sobre o valor de verdade das sentenças, pois tais “questões pertencem ao domínio dos juízos. (...) No juízo, há o reconhecimento de sua verdade, ao passo que nas sentenças há a 'mera apreensão de um pensamento"' (FREGE, 1979 apud ARAÚJO, 2004, p. 69), descartando, assim, a possibilidade discriminatória de tais enunciados.

No esforço de se atingir a verdade ou mesmo de compreendê-la, salienta-se, ainda nesse momento, a presença inquiridora, e não menos importante, de Edmund Husserl (1859-1938) e sua filosofia fenomenológica, mais "precisamente aquela do método fenomenológico que tanto influiu nos mais importantes movimentos do pensamento do século XX" (GALEFFI, 2000, p. 15).

A fenomenologia, como método de se chegar à verdade, "ciência das essências", tem, como cerne, o fenômeno, termo de origem grega que significa "aquilo que aparece", que se torna visível e apreensível à consciência, entendendo-se uma relação dual entre o sujeito e tudo aquilo que o cerca, conforme assevera Galeffi (2000, p.25), uma "relação indissociável entre o sujeito e o mundo, a consciência e seus objetos". Interessante ainda apontar o "estatuto fenomenológico do signo", que, para essa abordagem, centra-se sobre o fundamento de que a consciência apreende não a coisa ou mesmo o signo diretamente que ela representa, mas sim tem-se a percepção "consciencial" que o signo representado gera na consciência (WAHL, 1970).

Nesse sentido, a consciência não é algo em si mesma, independente da relação sujeitoobjeto, mas só se constitui, enquanto relação com algo que a faz existir. Logo, a fenomenologia, nessa perspectiva, não prescinde do elemento humano no fazer existir das coisas, dando-lhes, inclusive, existência significativa.

A ação significativa do homem sobre o mundo, bem como a constituição da significação, encontra sintonia com os fundamentos teóricos da semiótica greimasiana, a qual valoriza a percepção e visadas humanas no processamento da significação e na sua apreensão, ainda amparada nos alicerces fenomenológicos.

Somente o ser humano pode decidir de que forma pretende estar-no-mundo, sobretudo quando aprender a se dar conta de que ele está aberto no mundo, e de que o "mundo" são todas as possibilidades. E é diante delas que os seres humanos são ou deixam de ser, se tornam e se transformam, exercem seus sonhos e desejos, vivem ou desistem de viver, se fazem dignos ou simplesmente rastejam como animais invertebrados. (GALEFFI, 2000, p.35)

$\mathrm{Na}$ década de 1940, a visada merleau-pontyana estende criticamente as contribuições da fenomenologia husserliana no sentido de não mais conceber a cisão entre corpo e mente, 
consciência e mundo circundante, como se o homem, cerne da consciência, estivesse apartado desse. Ao contrário, é a percepção que se tem do mundo que funda as noções de verdade e realidade, uma vez que "buscar a essência da percepção é declarar que a percepção é não presumida verdadeira, mas definida por nós como acesso à verdade" (MERLEAU-PONTY, 2006 [1945], p.14). E a importância do homem, em seu conjunto, e não mais uma concepção meramente "consciencialista" (empirista e intelectualista) que este faz das coisas, que interessa a esse campo inovador de análise fenomenológica. Daí, possivelmente, o porquê da referência que Greimas (1976 [1966]) faz do filósofo, calcando-se, nessa renovadora episteme, os alicerces fundantes para a consolidação da arquitetura semiótica, como se pode notar em uma das reflexões, trazida por Merleau-Ponty, no prefácio à fenomenologia da percepção.

O mundo fenomenológico não é o ser puro, mas o sentido que transparece na intersecção de minhas experiências com aquelas do outro, pela engrenagem de umas nas outras; ele é portanto inseparável da subjetividade e da intersubjetividade que formam sua unidade pela retomada de minhas experiências passadas, em minhas experiências presentes, de experiências do outro na minha. (MERLEAU-PONTY, 2006 [1945], p.18)

Assim como Frege, Husserl e Wittgenstein, outros filósofos da linguagem, a exemplo de Merleau-Ponty, contribuíram também com uma vasta gama de análises sobre a linguagem, sem descartar fundamentalmente a compreensão do mundo através da relação entre as palavras para o que elas designam. Como o ato de significar também faz parte da natureza humana e do mundo cultural, o homem, remetendo-se à epígrafe desse capítulo, "de manhã à noite e da idade pré-natal à morte, é atormentado por significações que o solicitam por toda parte, por mensagens que o atingem a todo o momento e sob todas as formas" (GREIMAS 1976 [1966], p. 15). Assim, esse mesmo homem é sempre convidado ao espanto, quando observa que a ordenação da vida humana se viabiliza pela linguagem, mais precisamente pela língua (língua natural), uma vez que é a partir desta que o homem se individualiza, constrói e exterioriza subjetividade e estabelece laços com outros humanos por meio de "valores grupalmente compartilhados" (LOPES, 2007 [1975], p.17).

A percepção da realidade fenomênica (realidade que se manifesta, que aparece) mais imediata, mais próxima ao homem, àquela do mundo sensível, só é possível quando se opera com a linguagem em suas mais diversas modalidades. A linguagem, entendida nesse contexto, como um constructo mental que intermedia o homem no mundo, ou, segundo Greimas e Courtés ([s/d], 2008), como um "conjunto significante", tem, nas línguas naturais, sua principal representante, por se constituir num primeiro sistema sígnico (semiótico), dotado de características articulatória e combinatória.

As línguas naturais ocupam a posição hierárquica predominante entre todos os sistemas semióticos porque elas constituem a única realidade imediata para o pensamento de cada um de nós seres humanos. [...] As línguas naturais constituem o único código capaz de traduzir com a máxima eficiência e adequação qualquer outro sistema semiótico. (LOPES, 2007 [1975], p. 20)

É com o sistema semiótico "natural", ou seja, aquele que constitui o cerne das línguas naturais, cuja estrutura mais básica (relação "som" e "coisa" ou, na configuração binária saussuriana, significante/significado) que o homem consegue entrar em contato com a significação, entendida como uma relação indissociavelmente necessária, numa "pressuposição recíproca" entre o significante e o significado, ou seja, "a existência do significante pressupõe, 
pois, a existência do significado. Por outro lado, o significado só é significado porque "existe um significante que o significa" (GREIMAS 1976 [1966], p. 17).

Lopes (1997) salienta, inclusive, que, anterior a essas preocupações mais recentes, F. de Saussure já apresentava, em suas aulas, alguns apontamentos referentes às relações entre os aspectos perceptivos e cognitivos, considerando a importância do sujeito observador na apreensão e definição do objeto, mais propriamente o que seria "noção de ponto de vista".

A noção de ponto de vista saussuriana (re)insere o fundamento de que o objeto de observação é percebido a partir do sentido dado pelo olhar de um sujeito, haja vista que "sujeito e objeto unem-se em solidariedade, por mútua implicação: não há objeto sem sujeito nem viceversa, sujeito sem objeto" (LOPES, 1997, p.112). Dessa forma, o objeto não é dado a priori, mas só é concebido no processo relacional com o sujeito observador.

Ora, para aquele contexto inicial da linguística, a presença de um sujeito observador prenuncia o advento teórico que cuida dos imbricamentos entre sujeito e objeto, elementos imprescindíveis para a ação semiótica, cujo entrelaçamento gera e realiza a significação. Analogamente a esse fundamento saussuriano, pode-se, então, pensar que a relação (r) entre o sujeito observador (s) e objeto $(\mathrm{O})$ - equacionada como se $\mathrm{R}_{\mathrm{X}} \mathrm{O}$ - seriam as primeiras noções do processo de percepção sígnica no "ato de conhecer" (LOPES, 1997).

O projeto teórico-científico de Saussure, fundamentado nas relações de diferença entre os constituintes mínimos da língua e da ação perceptiva do destinatário, quando em contato com o segmento linguístico, também trouxe contribuições para o campo metodológico da percepção semiótica. Ainda, segundo Lopes (1997), o destinatário-ouvinte apreende a langue a partir de uma operação simultânea de análise e síntese, na decomposição e composição das estruturas mínimas da parole, identificando, assim, o sistema linguístico pelo exercício da diferenciação.

A identidade de um dado segmento da cadeia significante só se revela na adoção, pelo destinatário (ouvinte ou leitor), da perspectiva sintética, com a qual ele promove o julgamento da identidade, recortando a fala do outro em unidades idênticas, do sistema da langue, com a finalidade de compreendê-la. Assim, o que era diferença no nível da manifestação da fala, e o que era dicotomia, no nível menor, de uma perspectiva analítica, vem a ser interpretado como idêntico, em nível maior, da perspectiva sintetizada da langue. (LOPES, 1997, p.119)

O ato da interpretação, acompanhado pela ação de reconhecimento dos elementos sistêmicos, ganha, nesse momento de encorpamento teórico, destaque e importância na constituição das significações que a própria dinâmica das línguas naturais possibilita. Assim, a abordagem estrutural sobre a língua elabora os fundamentos conceptuais sobre o signo, como também aspectos que o caracterizam, principalmente no tocante às facetas sígnicas indissociáveis: significante e significado.

Tomando-se essa dimensão perceptiva do signo, as línguas naturais (conjuntos significantes) se apresentam, então, como um sistema semiótico primordial, possibilitando ao homem construir e reconstruir o meio onde vive, produzir bens materiais e morais (valores que regulam a vida em sociedade), bem como transmiti-los aos seus descendentes e compartilhá-lo com outros com os quais convive. Compreende-se também que cultura e linguagem estão tão intimamente ligadas que se torna difícil e quase inapreensível percebê-las individualmente. Questão, aliás, como visto, bastante antiga e polêmica, uma vez que o mundo cultural é forjado pela ação do homem via linguagem, via atribuição de sentido às coisas e aos eventos que o cercam, como também a linguagem "aparece" quando da necessidade de se materializar o pensamento. De toda sorte, ou mesmo independente quem é herdeira de quem, a ação humana é possível, na medida em que se tem e se faz uso de um "instrumento" mediador que permite tal ação. 
Interpretar, nomear e significar, compreender e atribuir sentidos para além daquilo que a "coisa" é ou desempenha no mundo circundante, isto é, transcender a significação, como também abstraí-la, constituem-se tarefas complexas realizadas cotidianamente por todos os seres humanos, inclusive pelas crianças, por meio da língua. Constituída por uma rede sígnica, a língua possibilita o processo comunicacional e, sobretudo, hermenêutico do mundo.

A ação comunicativa, entendida como manifestação e atribuição significativa dos sentidos, viabilizada por meio das "palavras" e tomadas como a materialidade fônica significativa e o que mais se aproximaria da realidade sígnica, configura-se como um salto qualitativo da vida humana entre os outros demais seres, construindo, des-construindo e re-construindo as diversas formas de se estar no mundo, de relacionar-se com o outro e de produção material desse viver que se apresenta como a própria dinâmica cultural.

A manifestação dos sentidos humanos, mediatizados por signos, que se interpõem entre a "coisa" pensada e materializada, adquire um alcance de expressividade muito grande, porque, enquanto a "palavra" é uma entidade de pertencimento a um determinado sistema linguístico e, portanto, limitada e sem um caráter universalizante, o signo, por sua vez, apesar também de pertencer à cultura humana, rompe com os liames limitadores que um sistema linguístico pode impor. A "palavra", então, seria um engodo que ainda persiste, como uma estrutura linguisticamente acabada e pronta para exercer indiscutivelmente seu papel no processo comunicativo (GREIMAS; COURTÉS, [s/d], 2008).

$\mathrm{Na}$ contramão do sentido, as palavras afetam também os seres que as significam. As "afecções de alma", pensadas por Agostinho (VI d.C.), podem ser retomadas, na visada fenomênica, como artefatos simbólico-culturais que causam transformações que afetam a materialidade corporal, mas que são originariamente advindas de "transformações incorpóreas" (DELEUZE; GUATARRI, 1995).

O conjunto das expressões humanas, tomadas como enunciados, exerce ação mobilizadora nos "corpos", que não se restringem apenas ao corpo físico, mas também a outras dimensões corporais, como ao corpo de valores sociais e morais, os quais distinguem e caracterizam as sociedades. Tais ações mobilizadoras corresponderiam às "transformações incorpóreas" que, conjuntamente com as enunciações (palavras de ordem) que afetam os sentidos (paixões), perfazem o todo complexo social estruturado pela linguagem.

A paz e a guerra são estados ou misturas de corpos muito diferentes; mas o decreto de mobilização geral exprime uma transformação incorpórea e instantânea dos corpos. Os corpos têm uma idade, uma maturação, um envelhecimento; mas a maioridade, a aposentadoria, determinada categoria de idade, são transformações incorpóreas que se atribuem imediatamente aos corpos, nessa ou naquela sociedade. (DELEUZE; GUATTARI, 1995, p.19)

Por meio dessa via analítica, é possível considerar as palavras como verdadeiramente representações que, mediadas pelos "corpos", afetam os sentidos e elaboram reações e atos transformadores, alavancados pelas enunciações. Visualiza-se, a partir dessa dinâmica transitiva da palavra, o paradoxo que se instala, pensado na relação constitutiva entre a natureza imaterial da mesma e a potência que provoca a materialidade transformadora, o que se configura como o "milagre dialético constante", isto é, aquilo "que transforma a matéria em sentido; o conteúdo em expressão; o processo social, em sistema significante" (DELEUZE; GUATTARI, 1995, p.31).

Indo em direção ao campo da estrutura elementar da língua, o signo aparece como esse elemento primaz de contato que se interpõe entre o homem e o meio que o circunda. $\mathrm{O}$ signo desempenha um papel fundamental para o homem, uma vez que somente esse, na natureza, 
consegue atribuir sentido às coisas, demarcar o tempo (presente, passado e futuro) e, dentre tantas outras inúmeras interferências, criou um sistema simbólico limitado, composto por estruturas fônicas, que combinadas entre si, possibilitam-no materializar seu pensamento e estabelecer a comunicação com outros de sua espécie.

O signo, entretanto, não estabelece sentido sozinho, isolado, mas sim numa cadeia significante, comparado a uma engrenagem de uma máquina, cujo funcionamento não depende apenas de uma única peça, porém do arranjo articulado entre elas. Assim, se pode analogamente tomar a significação constituída pelo ato semiótico, "em seu aspecto coletivo" (DELEUZE; GUATTARI, 1995). Interessante ainda, nessa breve visada fenomenológica, as afinidades percepto-interpretativas, consideradas por Landowsky (2005), entre os empreendimentos teóricoepistemológicos de Algirdas Greimas e Paul Ricœur, mais propriamente, Ricœur como comentador crítico de Greimas.

No tocante ao processamento da significação, Landowsky (2005) retoma as atividades desenvolvidas "entre o hermeneuta e esse tal semioticista", apresentando as contribuições atentas de Ricœur ao método semiótico greimasiano (percurso gerativo de sentido), mais especificamente nas passagens de um nível de significação a outro, do mais profundo ao superficial, compondo, assim, a completude de sentido.

A cada mudança de nível, há investimentos de natureza axiológica, mas não de forma tão direta e até mecânica, como propõe o modelo, pois, se assim fosse, seria uma mera transposição o que, na verdade, não daria conta da complexidade narrativa que envolve o ser e o agir dos sujeitos actantes, eu, segundo Landowsky, 2005, p.237): “(...) Com certeza, como toda axiomática bem construída, a sintaxe elementar do nível inicial basta-se em si mesma; mas como tal, não permite dar conta por simples 'conversão' do agir do actante do relato".

Ou seja, o modelo de análise semiótica exige relações complexas entre as estruturas semânticas e sintáticas, as quais vão sendo construídas ao longo do percurso (de um patamar a outro), na dependência também do sujeito produtor da significação (sujeito observador), "Porque longe de ser redutível a uma série de puras operações lógicas do tipo da asserção e da negação, o fazer antropomórfico que constitui o motor da intriga adquire seu sentido somente em função de uma inteligência narrativa pressuposta" (LANDOWSKY, 2005, p.237).

Ainda, segundo Landowsky (2005), na esteira de Ricœur, a "inteligência narrativa pressuposta", em uma atitude nada previsível, vai realizando uma "semântica da ação", compondo uma "fenomenologia do padecer", cuja significação não é previamente dada, e sim formada pela articulação e arranjos entre os constituintes da narrativa e o sujeito que observa.

A essa fenomenologia implicitamente (ou sub repticiamente) convocada pelo modelo devese o fato de que um relato seja em definitivo sempre 'mais rico' do que a estrutura lógicosintática que, em certo sentido, prefigura seu desenvolvimento discursivo. Aliás, sublinhava Ricœur, se o fazer dos atores estivesse inteiramente previsível e calculável a partir da axiomática inicial, não se passaria nada - nada de novo - e não haveria simplesmente nada a contar. (LANDOWSKY, 2005, p. 237)

A abordagem fenomenológica, encarada e tomada pela semiótica greimasiana, longe de negar a presença e a importância do homem na composição do percurso gerativo, atrela-o a uma relação indissociável com o fazer interpretativo e significativo. Assim, conceitualmente, a semiótica, nesses termos, não se configura como a relação entre signos, mas em uma teoria que se preocupa em "explicitar, sob forma de construção conceitual, as condições da apreensão e da produção do sentido" (GREIMAS; COURTÉS [s/d], 2008, p. 453). 
Torna-se, portanto, no mínimo curioso, a inserção da fenomenologia nos fundamentos da semiótica de natureza estrutural, uma vez que essa apresenta, como pressuposto, um modelo estrutural da significação, invariante, concebido como a hierarquia dos níveis gerativos (percurso gerativo de sentido), sobre o qual se movem, articulam-se os elementos variantes (talvez fenomenológicos?) que constituem o sentido.

\section{REFERÊNCIAS}

AGOSTINHO, Aurelius. [séc.IV d.C). De Magistro. Tradução de Bento Silva Santos. Petrópolis, RJ: Vozes, 2009.

ARAÚJO, Inês Lacerda. Do signo ao discurso: introdução à filosofia da linguagem. São Paulo: Parábola, 2004.

DELEUZE, Gilles. Platão e o simulacro. In. . Lógica do sentido. 4. ed. São Paulo: Perspectiva, 2000. p.259-71.

DELEUZE, G.; GUATTARI, F. Mil Platôs: capitalismo e esquirofrenia. Tradução Ana Lúcia de Oliveira e Lúcia Cláudia Leão. São Paulo: Ed.34, 1995. v. 02.

GALEFFI, Dante Augusto. O que é isto - a fenomenologia de Husserl? Revista Ideação, Feira de Santana, n.5, p.13-36, jan./jun 2000.

GREIMAS, Algirdas Julien. Semântica estrutural. Tradução Haquira Osakabe e Izidoro Blikstein. São Paulo: Cultrix/EDUSP, 1976 [1966].

GREIMAS, A. J.; COURTÈS, J. [s/d]. Dicionário de Semiótica. 7. ed. São Paulo: Contexto, 2008.

GREIMAS, Algirdas Julien; FONTANILLE, Jacques. Semiótica das paixões: dos estados de coisas aos estados de alma. Tradução Maria José Rodrigues Coracini. São Paulo: Ática, 1993.

LANDOWSKI, Eric. Entre Ricouer e Greimas, in memoriam. Revista Galáxia: revista transdisciplinar de comunicação, semiótica e cultura, São Paulo, n.9, p. 235-241, out. 2005.

LOCKE, John. Ensaio acerca do entendimento humano. Tradução de Anoar Alex e Jacy Monteiro. 5.ed. São Paulo: Nova Cultural, 1991 [1690].

LOPES, Edward. A identidade e a diferença: raízes históricas das teorias estruturais da narrativa. São Paulo: EDUSP, 1997.

PLATÃO. [séc. V a.C]. A República. Tradução de Ma. Helena da Rocha Pereira. 8.ed. Porto: Calouste Gulbekian, 1996.

SAUSSURE, Ferdinand de. Curso de lingüistica geral. Tradução de Antônio Chelini et al. 28. ed. São Paulo: Cultrix, 2006 [1916].

WAHL, François. Estruturalismo e Filosofia. Tradução de Alfredo Bosi e Adélia Bolle. São Paulo: Cultrix, 1970.

WITTGENSTEIN, Ludwig J. J. Investigações Filosóficas. Tradução José Carlos Bruni. São Paulo: Nova Cultural Ltda., 1999 [1945].

Recebido em: 02/05/2017

Aprovado em: 08/08/2017

Publicado em: 01/12/2017 